\title{
研究
}

\section{銅ニッケル合金の高温スパッタリング : \\ イオン誘起拡散と金属組織の役割}

\author{
清 水 肇* \\ （昭和56年12月 5 日 受理）
}

High Temperature Sputtering of $\mathrm{Cu} / \mathrm{Ni}$ Alloy:

Roles of Ion-Enhanced Diffusion and Grain Boundary Erosion.

\section{Hazime SHIMIZU}

(Electrotechnical Laboratory, 1-1-4 Umezono, Sakura-mura, Niihari-gun, Ibaraki, 305 Japan)

(Received December 5, 1981)

Structural and compositional modifications were investigated in the sputter-damaged surface layer of $\mathrm{Cu}-$ 40 at $\% \mathrm{Ni}$ alloy specimens at elevated temperatures by means of Auger electron spectroscopy (AES), X-ray microscopy (XMA), scanning electron microscopy (SEM) and electron channeling pattern (ECP) method. A long range depletion of copper was found in the layer beyond the trajectories of the primary ions. The apparent activation energy of the ion-enhanced volume diffusion was only $5.4 \pm 0.5 \mathrm{kcal} / \mathrm{mol}$, suggesting that interstitial type diffusion was dominant. The active diffusion was also found along grain boundaries.

\section{1.はじめに}

合金や化合物を低エネルギー希ガスイオンで衝撃する と，表面近傍で組成変化が起ることがオージェ電子分光 法 (AES) 等の表面分析法で明らかにされた ${ }^{1)}$. 清浄表 面の作成や元素の深さ方向分布を希ガスイオンスパッタ リングで求める場合に注意しなければならない現象であ る2). また最近では核融合炉壁の損傷の問題がクローズ アップされるにつれて, 表面から放出される物質の種類 や濃度に影響を与える素過程としても重要視され, 耐イ オン損傷材の開発を行う上でも現象の本質的な理解が必 要とされている

銅ニッケル合金は全率固溶体を作り，単相で広い範囲 にわたって組成を変えることが出来，古くから物性基礎 データが良く調べられている物質である。 また周期律表 では隣接する元素であるので，オージェ電子の遷移確 率, 平均脱出深さ, 背面散乱電子効果などが類似してい て定量的な解釈を行う上で都合が良く，表面分析の標準

\footnotetext{
* 電子技術総合研究所 (茨城県新治郡桜村梅園1-1-4)
}

試料としても用いられている。しかもスパッタ率は銅の 方がニッケルより大きいこと源，合金中での 拡散定数 は銅の方がニッケルより約 1 桁大きいことのため ${ }^{8,9)}$, こ の合金は選択スパッタリングや照射損傷のモデル実験を 行ら系として適している。このため，この合金のイオン 衝撃に関する研究は多数報告され, 研究手段としても AES の他に 2 次イオン質量分析法 (SIMS) ${ }^{10}$, イオン散 乱分光法 (ISS) ${ }^{11,12)}$ なども用いられ，組成変化に関して 多角的な検討が進められてきている. しかし銅ニッケル 合金のイオン衝撃による表面組成変化が，選択スパッタ リングに起因するものであるか否かという基本的な疑問 は，いまだに明らかにされていない.

筆者はすでにこの合金の希ガスイオンによるスパッタ リング現象を室温から 873K の温度範囲で $\mathrm{AES}^{13 \sim 15)}$, $\mathrm{X}$ 線マイクロアナリシス法 $(\mathrm{XMA})^{16)}$ を用いて調べ, 試料の表面ならびに深い領域での組成変化 ${ }^{17)}$, イオン誘 起拡散と表面偏析の役割 ${ }^{18,19)}$ について報告してきた. 高 温スパッタリングについてはRehnら ${ }^{20)}$, Shikata ${ }^{21)}$, 柿林ら ${ }^{10)}$ ，Swartzfagerら ${ }^{12)}$ による報告があって，表面層 
や深い層での組成変化については調べられているが，現 象を統一的に説明出来る結果は得られていない. また銅 原子の促進された拡散の機構についての検討もなされて いない，本研究ではイオン誘起拡散に及ぼす照射条件， 試料温度，金属組織の影響を系統的にまた定量的に調 ベ，イオン誘起拡散定数，拡散の活性化エネルギーの算 出を試み，拡散機構の決定を行う。その結果に基づき室 温スパッタリングによる組成変化に果す照射誘起拡散の 役割を明らかにし，銅ニッケル合金の選択スパッタリン グについて論じる.

\section{2. 実験}

\section{(a) 試 料}

実験に用いた Cu-40 at\% Ni 合金*の薄板銅は (99, 99 at \%) とニッケル (99.9 at\%) を真空溶解して得た. 試 料は熱間圧延で約 $1 \mathrm{~mm}$ 厚にした後に, 冷間圧延で 0.2 $\sim 0.3 \mathrm{~mm}$ にした. 圧延による歪の除去と再結晶による 粒径成長のために，薄板を $1000 \sim 1300 \mathrm{~K}$ で 10 時間以上真 空焼鈍を行った. 焼鈍温度や圧延条件によって試料の平 均粒径は $50 \sim 600 \mu \mathrm{m}$ のものが得られる。しかし大きい 粒径のものでも焼鈍双晶がかなり含まれていることが多 い. 走查電子顕微鏡 (SEM) や光学顕微鏡で平均粒径を 確認したものを実験に用いた。 また粒界損傷の影響を減 らすために粗大粒試料を作成した，焼鈍した試料に軽い 冷間圧延を行い再び融点近くで焼鈍すると，平均粒径が $1 \sim 3 \mathrm{~mm}$ の試料が得られた.

圧延傷や焼鈍によって組成の変化した表面層を除くた めに, 水, 硫酸, リン酸混合液中で電解研磨 ${ }^{22)}$ を行い, 鏡面の得られた試料を実験に用いた. このようにして得 た表面の銅とニッケルの組成は母相とほぼ同一であるこ とを AES で確認した. 試料片 $\left(5 \times 3 \mathrm{~mm}^{2}\right)$ を 3 個 加熱用タンタル薄板に点溶接して回転試料ホルダーに取 り付けた． 加熱には温度制御用の電源 ${ }^{23)}$ を用い，温度測 定には $\mathrm{Pt} / \mathrm{Pt} \cdot \mathrm{Rh}$ 熱電対を用いた. 室温から $873 \mathrm{~K}$ まで の昇温に要する時間は $5 \sim 6$ 秒で, 設定温度精度は土 5 度であった. 試料ホルダーの熱容量が効くために, 降温 速度は加熱温度と持続時間に依存するが,おおよそ873 $673 \mathrm{~K}$ 間が $5 \sim 6$ 秒， $473 \mathrm{~K}$ まで20 30秒である. それ以 下室温になるまではかなり長くかかった.

\section{（b）イオン衝撃}

スパッタリングは熱電子衝撃型の小型イオン銃を用い て，オージェ分析装置内で行った. $423 \mathrm{~K}$ 近傍で約 6 時 間焼き出しを行った後の装置の圧力は $5 \sim 8 \times 10^{-8} \mathrm{~Pa}$ で, 残留ガスの主なるものは $\mathrm{H}_{2}, \mathrm{CH}_{4}, \mathrm{H}_{2} \mathrm{O}, \mathrm{CO}, \mathrm{CO}_{2}$ 等である.スパッタ中はターボ分子ポンプで排気を行い

* 以後 $40 \mathrm{at} \% \mathrm{Ni}$ と呼ぶ
ながら $3 \times 10^{-3} \mathrm{~Pa}$ 程度の $\mathrm{Ar}$ ガスを導入し,不純物濃度

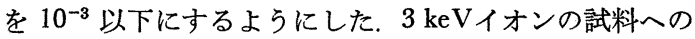
入射角を垂直にするために，イオン衝撃中は試料をAES 分析の位置から移動した。 また入射イオン密度を正確に 測るために, 試料表面近くにアース電位にしたタンタル 製の空 $\left(5 \times 5 \mathrm{~mm}^{2}\right)$ を取り付けた. 2 次電子放出による イオン電流の補正は，試料に正のバイアス $(40 \mathrm{~V})$ を印 加して行ったが，2 次イオン放出効果は極めて小さいの で無視した. 入射イオン密度は $4 \times 10^{-8} \sim 8 \times 10^{-5} \mathrm{~A} /$ $\mathrm{cm}^{2}$ の範囲で変えた. 入射イオンによる試料の温度上昇 は, $40 \mu \mathrm{A} / \mathrm{cm}^{2}$ の場合室温の試料で10度程度であった. 高温スパッタリングは試料に通電を行いつつ行うが，熱 電対と測温用電圧計は外部電源から絶縁されているため に，温度測定へのイオン電流の影響はなかった。

\section{(c) 組成分析}

表面組成の分析には走查型オージェ分析装置 ${ }^{24,25)}$ を用 いた，組成の検量には LMM オージェ遷移による $\mathrm{Ni}$ $(710 \mathrm{eV})$ と $\mathrm{Cu}(920 \mathrm{eV})$ の 2 本のピークを用いた．流 水中でエメリー研磨して得た 10 at $\%$ 执きの 9 種類の合 金表面からのオージェスペクトルの強度比から銅とニッ ケルの表面組成を求める検量線を作成した. この検量法 による組成分析の精度は，表面に不純物が特に多くない 限り土5\%であった ${ }^{26)}$. なおスパッタ後の表面で観測さ れる僅かの不純物は $\mathrm{O} ， \mathrm{C} て ゙ ， \mathrm{~S}$ は認められなかった. 用いた装置の位置分解能は, $10 \mathrm{kV}$ の加速電圧で試料電 流を $2 \times 10^{-7} \mathrm{~A}$ とると約 $5 \mu \mathrm{m}$ であった. 本研究では電子 ビームを走査することによる面平均組成分析 $(1 \times 0.7$ $\mathrm{mm}^{2}$ ) と個々の結晶粒に対する点分析とを行った.

粒界近傍の組成, スパッタ堆積膜の組成をエネルギー 分散型 XMA で測定した. 分析にはニッケルの $\mathrm{K}_{\alpha 1}$ と $\mathrm{K}_{\alpha 2}(7477,7460 \mathrm{eV})$ と銅の $\mathrm{K}_{\alpha 1}, \mathrm{~K}_{\alpha 2}(8046,8026 \mathrm{eV})$ のピークを用いた. エネルギー分析器の分解能は $146 \mathrm{eV}$ で， $\mathrm{K}_{\alpha_{1}}$ と $\mathrm{K}_{\alpha 2}$ は 1 本のピークとして強度計算を行っ た. 検量線は 9 種類の合金から作成し，分析精度は土2 \%であった．XMA による組成分析は，試料をスパッタ 装置から取り出して行ったが，大気に試料をさらしたこ とによる影響は少ないと考えた.

スパッタ中に試料から放出される合金の平均組成は, 試料前部に取り付けたアパチャーにチタン薄板を点溶接 し，その上に堆積させた薄膜を XMA で分析して 調べ た. チタンの特性X線は銅とニッケルの $\mathrm{K}_{\alpha 1}, \mathrm{~K}_{\alpha 2}$ 線 と 重複しないので, コレクタ材として選んだ.チタン薄板に はアルミナ粉による研磨を行い，鏡面に仕上げた後に洗 浄を行って用いた. この面への銅とニッケルの付着確率 は同じと仮定した，XMA による分析を行うと，下地于 タンからのピークがかなり強いことが多く, 堆積膜その 


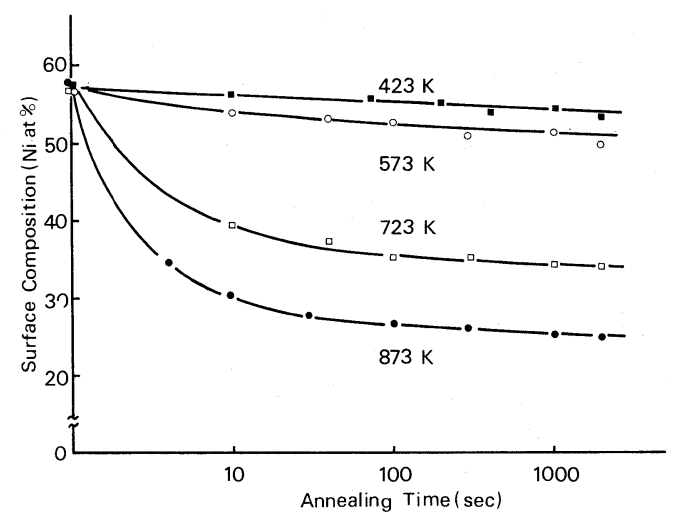

Fig. 1 Surface composition changes of 40 at $\% \mathrm{Ni}$ alloy determined by AES as a function of annealing time at various temperatures after $3 \mathrm{keV}$ argon ion bombardment at room temperature.

ものの厚みはかなり薄いと考えられ，そのため同一条件 で行った実験でも膜の組成の測定誤差は $5 \sim 7 \%$ 程度あ った. この誤差を小さくするために, 試料面上のかなり 広、領域を電子ビームを走査しつつ分析を行って平均組 成を求めた。

\section{（d）表面形態の観察之結晶方位解析}

イオン衝撃後の表面形状の変化は, 走査型 AES を用 いてその場観察を行った他, 高分解能 SEM も併用し た. 各結晶粒の方位解析ならびに粒界構造の解析には電 子チャンネリングパターン法 (ECP) を用いた ${ }^{27 ~ 29)}$. こ の手法の原理は, 電子線が格子面で Bragg条件を満足す る前後で異常吸収又は異常透過を起すという現象に基づ く. ECPを実際に得るためには，電子ビームを試料上の 一点に固定しながら Bragg 角 $(\theta)$ より大きく角度掃引 し, 試料上部におかれた半導体検出器で反射電子を測定 して, その強度変化でブラウン管の $\mathrm{Z}$ 軸輝度変調を行 う.このパターンから方位の判別を行らが, 実際の試料 では軸のずれなどがあるために，あらかじめ任意の方位 の ECP が描けるように計算機にプログラムを入力し て, 実測のデータと一致するように各種のパラメーター （軸方位の傾き, 回転角）などを変えながら方位決定を 行う. 本研究で用いた電子線角度偏向装置は $100 \mathrm{kV} の$ 透過電子顕微鏡（日本電子 $100 \mathrm{~B}$ 型）に取付けたものであ る. 方位解析に必要な最小粒径は $20 \mu \mathrm{m} \phi$ で, 方位の測 定精度は $\pm 0.1^{\circ}$ と比較的高い.

ECP をイオン損傷の実験に用いる場合の 問題点は, (1)表面に形成された微細な凹凸や，(2)表面近傍層の格子 の歪や格子欠陥による結晶の不完全性などによる ECP リボケである。こり現象は ECP 測定に使う電子線の加

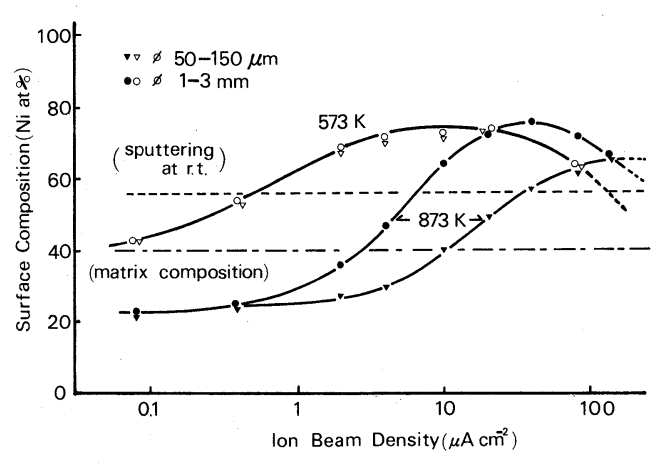

Fig. 2 The effect of argon ion dose rate on the surface composition of $40 \mathrm{at} \% \mathrm{Ni}$ alloy specimens with varied grain diameters. Ion bombardment was carried out for $30 \mathrm{~min}$ at 573 and $873 \mathrm{~K}$.

速電圧が低い場合に特に問題になる。 この場合には試料 を真空中で $773 \sim 873 \mathrm{~K}$ で焼鈍すると明瞭なパターンが多 くの場合観察される. 本研究ではあらかじめ方位解析を 行ってから照射実験を行らといら方法も併用した.

\section{3. 結果}

\section{（a） 高温照射による表面および母相の組成変化}

室温でこの合金にアルゴンイオン衝撃を行らと, 約 10 $\mathrm{nm}$ 剝離した後の表面ではニッケルの富化が AESで認め られる. XMA では変化が検出出来ないことから, 組成 変化が起っている領域は表面近傍に限られていることが わかる. Fig. 1 は平均粒径が300 500 $\mu \mathrm{m}$ の $40 \mathrm{at} \% \mathrm{Ni}$ 合金試料を室温でイオン衝撃した後に, 真空焼鈍によっ て起った表面組成変化を AES で測定した結果である. $573 \mathrm{~K}$ 以上では銅の偏析が認められるが, 偏析速度と平衡 濃度は焼鈍温度によって異なる。銅の偏析濃度は $873 \mathrm{~K}$ 以上ではほとんど変化しないが, 偏析速度はさらに大き くなると考えられる. イオン剝離法で推定した偏析層の 厚みは873Kでは $5 \sim 7 \mathrm{~nm}$ で, この厚みは焼鈍温度の低 下とともに減少した ${ }^{19)}$. 各温度での銅の偏析量は, 平均 粒径には依存しないが723K以上では細粒試料の方がや や偏析速度が大きくなる傾向がある. しかし変化が速い ために定量的な結果は得られなかった. また銅濃度の場 所による差は AES の分解能範囲では認められなかった。 高温スパッタリング中の表面近傍では，(a)選択スパッ タリング機構による銅の優先的剝離，(b)銅のイオン損傷 層を通しての表面偏析という 2 種類の現象が同時に起る ために, 表面組成は入射イオン密度, 温度に大きく依存 する. また本研究で扱 5 温度範囲は $1 / 2 T_{m}$ (融点: $\mathrm{K}$ ) 


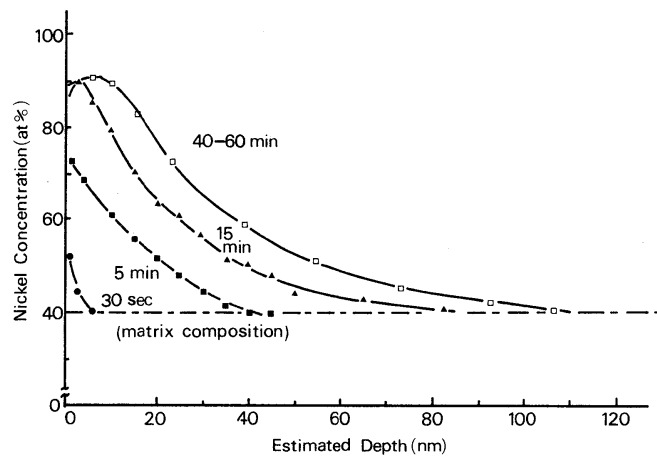

Fig. 3 The effect of argon ion sputtering time at $873 \mathrm{~K}$ on the depth profile of copper depleted region in a coarse grained 40 at $\% \mathrm{Ni}$ alloy specimen (diameter: 1-3 mm). Ion beam density was $20 \mu \mathrm{A} / \mathrm{cm}^{2}$.

以下であるために正常な体拡散機構に比較して, 粒界や 転位に起因寸るいわゆる短回路拡散の役割が重要になる $る^{31)}$. 以上の複合効果の表面組成への影響を調べる目的 で，平均粒径が大きく異なる 2 種類の $40 \mathrm{at} \% \mathrm{Ni}$ 合金 : (a) $(50 \sim 150 \mu \mathrm{m} \phi)$, (b) $(1 \sim 3 \mathrm{~mm} \phi)$ について, $573 \mathrm{~K}$ と $873 \mathrm{~K}$ でアルゴンイオン密度を変えながらイオン 衝撃 を行った後の AES で求めた組成変化を Fig. 2 に示し た. 試料温度が設定值になった後にイオン衝撃を開始 し， 1 時間後に 2 つの操作を同時に停止した. AESの測 定は室温近傍で行った.

$573 \mathrm{~K}$ の場合にはイオン密度が増すにつれて ニッケル 濃度がさらに増加するが，2 種類の試料間にはその挙動 に差はほとんど認められず，10 $\mu \mathrm{A} / \mathrm{cm}^{2}$ あたりで $73 \mathrm{at} \%$ $\mathrm{Ni}$ 相当になり最大值を示す.さらにイオン密度を上げ るとややニッケル濃度が減少し $80 \mu \mathrm{A} / \mathrm{cm}^{2}$ では $60 \sim 65$ at $\% \mathrm{Ni}$ 相当となる. 一方 $873 \mathrm{~K}$ ではイオン密度が低い場 合には 23 at\% Ni 相当の組成で, Fig. 1 亿示した 銅の 偏析効果が著しいことがわかる，入射イオン密度の増 加によるニッケル富化現象には明瞭な結晶粒径依存性が 認められ， $2 \mu \mathrm{A} / \mathrm{cm}^{2}$ のイオンに対して細粒では $25 \mathrm{at} \%$ $\mathrm{Ni}$ であるのに対し，粗大粒では $35 \mathrm{at} \% \mathrm{Ni}$ となる。 オン密度の増加とともに両者の濃度差はさらに大きくな った後に次第に小さくなるが， $40 \sim 80 \mu \mathrm{A} / \mathrm{cm}^{2}$ でも 15 at \% Ni 以上の差がある. 573，873K での表面組成は各 結晶粒間でほとんど差が AES では認められなかった.

スパッタリングによって㸚離される物質の大部分は表 面 1 ～ 2 原子層から放出されると考えられるので，表面 組成がイオン照射条件や試料の平均粒径によって変化す ることは, 放出される物質ならびに母相内での組成にも 変化が起ることを予想させる.Fig. 3 は 40 at \% Niの粗

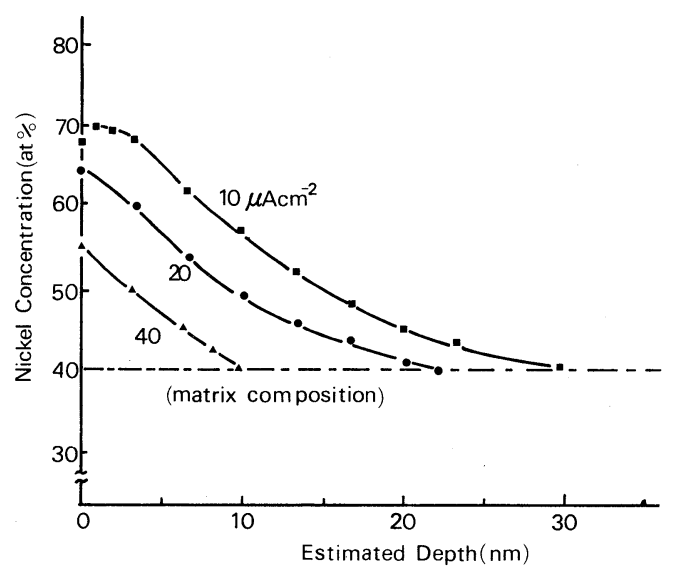

Fig. 4 The effect of argon ion beam density on the depth profile of copper depleted region at $573 \mathrm{~K}$ in a coarse grained $40 \mathrm{at} \% \mathrm{Ni}$ alloy specimen. The total ion dose was kept constant at $80 \mu \mathrm{A} \cdot \mathrm{h} / \mathrm{cm}^{2}$.

大粒試料を $20 \mu \mathrm{A} / \mathrm{cm}^{2}$ のイオン密度， $873 \mathrm{~K}$ で時間を変 えながらスパッタした場合の母相内の組成変化の深さ分 布を測定した結果である. 深さ方向分析は試料が室温に なった後に, $3 \mathrm{keV}, 4 \mu \mathrm{A} / \mathrm{cm}^{2}$ のアルゴンイオンで行 い，測定中に起る選択スパッタリング効果を補正した濃 度值を図中には示した. 墚さ方向の推定には $3 \mathrm{keV}$ のア ルゴンイオンによる銅のスパッタ率 (4.0 atoms/ion) か ら計算した剝離速度を用いた. いずれの場合も銅の欠乏 層の形成が認められる.イオン衝撃時間が長くなるにつ れて表面近くでのニッケル富化度合が強まる一方，欠乏 層も表面から梁くなる. この富化層の深さは $110 \mathrm{~mm}$ 程 度で平衡になり，その形成に要する時間は40 60分程度 である. 表面のスパッタ剝離の進行にもかかわらず，試 料内部に銅の欠乏層が形成されたことは銅の表面近傍へ の拡散が速く，欠乏層が平衡状態になるまでは銅のスパ ッタ量が多いことを意味する．イオン損傷による銅の促 進された拡散機構を明らかにするために，銅欠乏層の形 成に及ぼすイオン密度, 温度の影響を測定した。

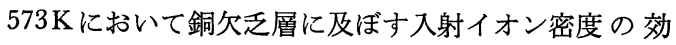
果を $40 \mathrm{at} \% \mathrm{Ni}$ 合金の粗大粒試料を用いて測定した結果 をFig. 4 に示した. 照射量を一定值 $80 \mu \mathrm{A} \cdot \mathrm{h} / \mathrm{cm}^{2}$ 以上 に保ってイオン密度を $40,20,10 \mu \mathrm{A} / \mathrm{cm}^{2}$ と変えながら スパッタした. 欠乏層の深さは平衡值が得られているこ とを確認した. 欠乏層け深さは $40,20,10 \mu \mathrm{A} / \mathrm{cm}^{2}$ リイ オン密度に対してそれぞれ10，22，30 nm 程度で，おお むね入射イオン密度に逆比例して深くなることがわかっ た.

銅欠乏層の状態がイオン衝撃条件に依存することは， 


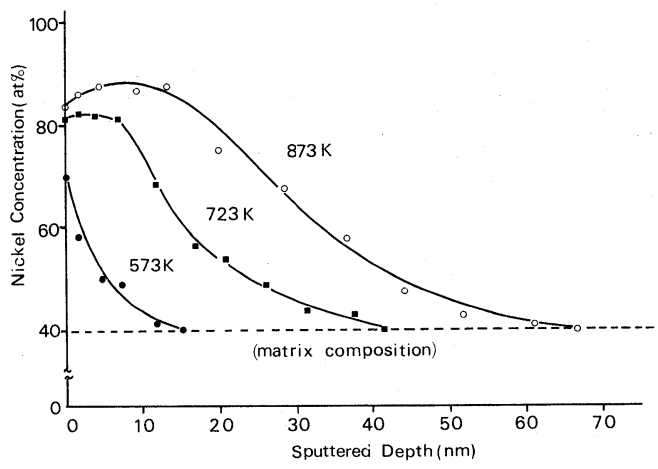

Fig. 5 The effect of sputtering temperature on the depth profile of copper depleted region in a coarse grained $40 \mathrm{at} \% \mathrm{Ni}$ alloy specimen. Ion bombardment was carried out for $1 \mathrm{hr}$ at current density of $40 \mu \mathrm{A} / \mathrm{cm}^{2}$.

表面からスパッタ放出される物質の組成も照射条件によ ることを示唆する．放出物質を飛行中に直接分析が出来 ないので，チタン薄板に堆積させた膜の組成をXMAで 測定した. $40 \mathrm{at} \% \mathrm{Ni}$ 合金の中粒試料 $(100 \sim 400 \mu \mathrm{m} \phi)$ を $873 \mathrm{~K}$ で入射イオン量を $80 \mu \mathrm{A} \cdot \mathrm{h} / \mathrm{cm}^{2}$ に保って入射イ オン密度を変えてスパッタした場合の，母相ならびに薄 膜の組成を Table 1 亿示した。試料温度を高くしたの は，銅の拡散速度を大きくすることで，薄膜の組成変化 を調べ易くしたためである. $40 \mu \mathrm{A} / \mathrm{cm}^{2}$ では母相と薄膜 の組成はそれぞれ $37 \sim 38,42 \sim 43 \mathrm{at} \% \mathrm{Ni}$ でほとんど差 がない. $6.5 \mu \mathrm{A} / \mathrm{cm}^{2}$ では両者の差が現われ, $3.3 \mu \mathrm{A} /$ $\mathrm{cm}^{2}$ では 35 at $\% \mathrm{Ni}$ 以上にもなる. Fig. 4 で示したよ らに入射イオン密度の低下とともに久乏層が深くなるこ とに対応し，銅の優先的な剝離が起る. Fig. 3 に示した ように久乏層の形成は40 60分で定常状態になるので, その後は母相と同一組成を保って物質が剝離されるた め，薄膜内の銅濃度はそれ程高くならない。

銅の欠乏層形成に及ぼす温度の効果を測定した結果を Fig. 5 に示した。 入射イオン密度を $40 \mu \mathrm{A} / \mathrm{cm}^{2}$ に保っ て 40 at $\% \mathrm{Ni}$ の粗大粒試料を $573 \sim 873 \mathrm{~K}$ の各温度で 1 時 間衝撃した。 $573 \mathrm{~K}$ の場合は表面組成は 70 at $\% \mathrm{Ni}$ にな るが，約 $10 \mathrm{~nm}$ 損傷層を剝離すると母相にもどる. 723 , 873K では表面からやや母相内部にかけてニッケルがさ らに富化する領域があり，その後単調にニッケル濃度は 減少する.

\section{（b）銅の照射誘起拡散の解析}

高温スパッタリングによる表面組成変化は，イオン照 射による表面の剝離と銅原子の表面偏析, 照射誘起拡散 との釣合で決ることを前節で明らかにした．これらの素 過程を模式的にまとめた結果を Fig. 6 に示した. イオ

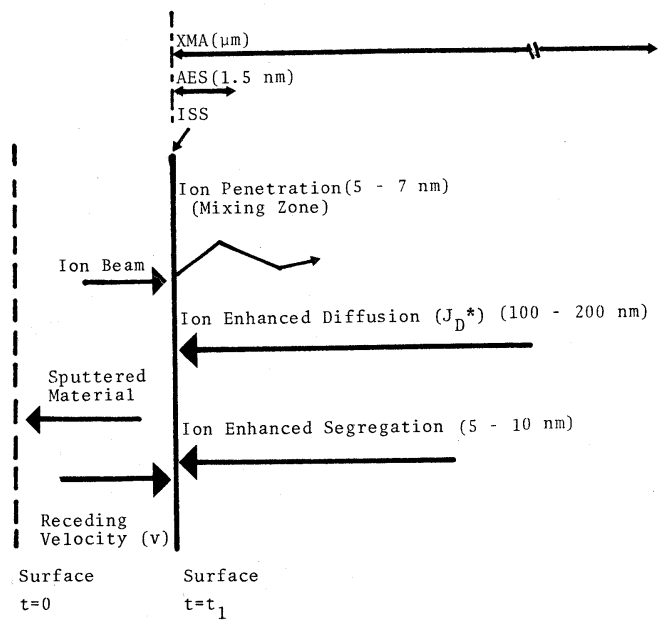

Fig. 6 Schematic model for mass balance during sputtering at elevated temperatures.

Table 1 Nickel concentration of the sputtered matrices and sputtered matrix by XMA from 40 at $\% \mathrm{Ni}$ alloy after sputtering $873 \mathrm{~K}$ with different ion beam densities. The total ion dose was kept constant at $80 \mu \mathrm{A} \cdot \mathrm{h} / \mathrm{cm}^{2}$.

\begin{tabular}{l|ccccc}
\hline $\begin{array}{r}\text { Ion beam density } \\
\left(\mu \mathrm{A} / \mathrm{cm}^{2}\right)\end{array}$ & 40 & 20 & 13 & 6.5 & 3 \\
Specimen & & & & & \\
\hline Matrix & 42 & 42 & 46 & 50 & 55 \\
Deposited film & 38 & 38 & 36 & 30 & 18 \\
\hline & & \multicolumn{5}{c}{$(\mathrm{Ni}$ at $\%)$}
\end{tabular}

ン損傷層内での銅の拡散機構を解明するためには，拡散 定数, 活性化エネルギー, 振動因子の測定 が 重要であ る.しかし Fig. 6 に示したように表面がイオン衝撃に よって㓦離され，その速度がイオン密度に依存するよう な条件の下では, フィックの第 2 法則に剝離効果を加え る必要がある．拡散定数 $D^{*}$, が損傷層内で一定であると いら第一次近似が行える場合には，濃度 $\theta(x)$ の時間変 化は $v$ を剝離速度とすると

$$
\frac{\delta \theta(x, t)}{\delta t}=D^{*} \frac{\delta^{2} \theta(x, t)}{\delta x^{2}}+v \cdot \frac{\delta \theta(x, t)}{\delta x}
$$

で示される.(1)式の非定常状態の解法はかなり複雑であ るが，濃度分布の定常状態に対する解は， Eltoukhy と Greene ${ }^{32}$ によって与えられ，

$$
\theta_{\mathrm{eq}}(x)=C+\left(\theta_{\mathrm{eq}}(0)-C\right) \exp (-x v / D)^{*}
$$

となる。なお $\theta_{\mathrm{eq}}(x)$ は表面から距離で $x$ のニッケル濃 度， $C$ は母相のニッケル濃度である. イオン衝撃を併用 して得た $\theta(x)$ から(2)式を用いて Fig. 4 における $D^{*}$ を 解析した. $40,20 \mu \mathrm{A} / \mathrm{cm}^{2}$ の照射条件ではあまり目立た 
ないが, $10 \mu \mathrm{A} / \mathrm{cm}^{2}$ では表面から数 $\mathrm{nm}$ の領域で銅の偏 析効果が認められて, 異った拡散機構に対応した欠乏層 が形成され式(2)を単純に適用することは問題になる。 こ こでは深い領域での拡散に注目しているので, $\theta_{\mathrm{eq}}(0)$ の 值には $x=0$ のかわりに表面から $3 \mathrm{~nm}$ の部分を除いた 值を，また $\theta_{\mathrm{eq}}(x)$ にも新しい $x$ 亿対応する值を用いた。 入射イオン密度が小さくなるとやや $D^{*}$ は小さくなる傾 向があるが，ほぼ $6 \sim 8 \times 10^{-15} \mathrm{~cm}^{2} / \mathrm{s}$ となった。 このこと は式(2)で $D^{*}$ がかなり広い損傷領域で一定であること， また本研究の条件では $D^{*}$ が入射イオン密度変化に対し てほぼ独立であることを意味する。

同様化式(2)を用いて Fig. 5 の結果から拡散定数 $D^{*}$ の 温度変化を求めた。 $723 ， 873 \mathrm{~K}$ の場合には表面から 15 $\mathrm{nm}$ 程度まで銅の偏析効果による濃度分布に不均一性が 認められるので，その部分を除いて単調にニッケル濃度 が変化する部分で $D^{*}$ の解析を行った. Fig. 7 に $D^{*}$ な らびに放射性同位元素法で間間) らが測定した体拡散定 数 $D_{\mathrm{vol}}$ の $55 \mathrm{at} \% \mathrm{Ni}$ の結果を示した。 また活性化エネ ルギー，振動因子を用いて低温度領域まで外挿した值を 破線で示した．銅の拡散定数は組成によっても異るが， 40 at \% Ni 合金は55at\% Ni 合金に近い值を示すと考え られる。体拡散定数とイオン誘起拡散定数はお打よそ $1000 \mathrm{~K}$ 近傍で交差し，この温度より低くなればなるほど イオン誘起拡散が相対的に活性になる. 拡散の促進度合 は，573，723 $873 \mathrm{~K}$ の各温度で比較してみると，4× $10^{8}, 1.3 \times 10^{4}, 20$ 倍となる.

体拡散定数の温度変化がアウレニウスの式に従らこと は知られている. Fig. 7 からわかる様に $D^{*}$ む $1 / T$ 亿対 して良い直線性を示すので，照射誘起拡散定数もアウレ ニウス型の温度依存性を示すとして, 次式から活性化エ ネルギー $E^{*}$ ならびに振動因子 $D_{0}{ }^{*}$ の解析を試みた.

$$
D^{*}=D_{0}{ }^{*} \cdot \exp \left(-E^{*} \mid k T\right)
$$

ここで $D_{0}{ }^{*}$ : 振動因子, $k$ : ボルッマン定数である. 得ら れたみかけの活性化エネルギー $E^{*}$ は $5.5 \pm 0.5 \mathrm{kcal} / \mathrm{mol}$ $(0.24 \pm 0.02 \mathrm{eV})$ であり，また振動因子 $D_{0} *$ は $7 \times 10^{-13}$ $\mathrm{cm}^{2} / \mathrm{s}$ であった。 な扔門間らによって報告された体拡散 に対する活性化エネルギーと振動因子はそれぞれ60～65 $\mathrm{kcal} / \mathrm{mol}, 0.2 \mathrm{~cm}^{2} / \mathrm{s}$ で著るしく異っている.このことは, イオン誘起拡散が主に格子閒原子によるもので，空孔の 移動によって起る正常な体拡散の機構と明瞭に異なって いることを示す有力な根拠である ${ }^{33-35)}$.

（c）イオン誘起拡散の室温スパッタリングに及ぼす 影響

室温におけるイオン誘起拡散定数 $D^{*}$ を, $D_{0}^{*}, E^{*}$ か ら外挿してみると， $0.7 \sim 1 \times 10^{-16} \mathrm{~cm}^{2} / \mathrm{s}$ 程度の值とな る.イオン損傷層内の銅が醉歩運動によって移動すると

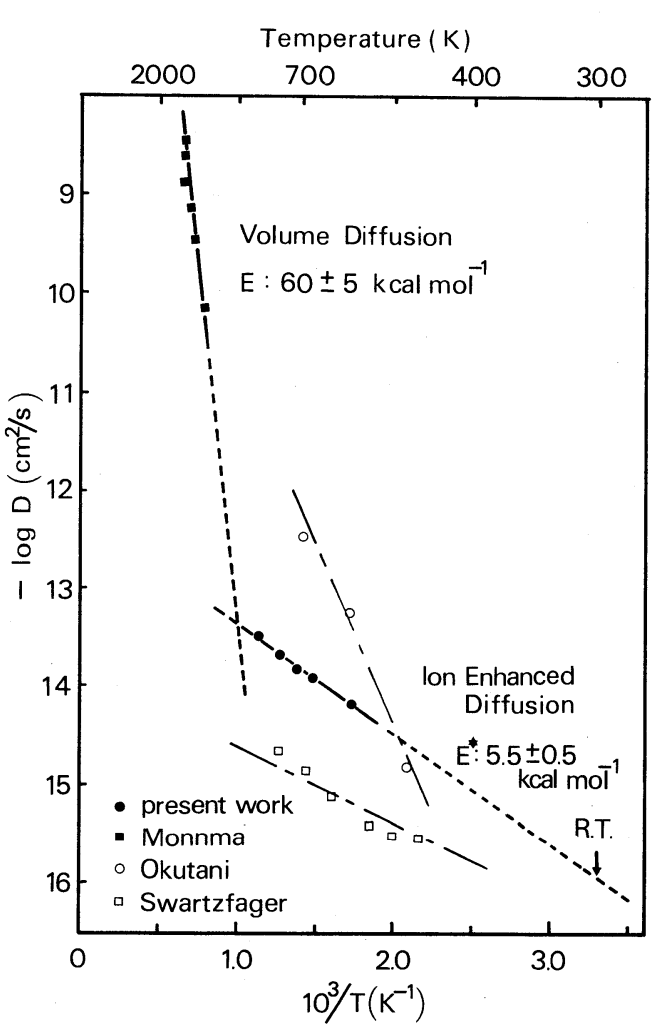

Fig. 7 The effect of temperature on the enhanced diffusion coefficients for copper in a coarse grained 40 at $\% \mathrm{Ni}$ alloy specimen. The normal diffusion coefficients were reported by monma et al.0. .

すると, 拡散距離 $\left(l=\sqrt{ } \overline{D^{*} \cdot t}\right)$ は室温においても銅原 子が数秒で格子間距離を単位として動けることを示す. このことは, 室温でのスパッタリングに㧍ける組成変化 を考える場合に，構成元素のスパッタ率のみならず， Fig. 6 に示した拡散の寄与も考慮する必要があることを 示している. Fig. 8 は $40 \mathrm{at} \% \mathrm{Ni}$ 合金の粗大粒試料を, $40 \mu \mathrm{A} / \mathrm{cm}^{2}$ のイオン密度で 1 時間以上イオン衝撃し, 表 面組成が室温での平衝值になったことを確認した後, $3 \mathrm{keV}$ のアルゴンイオンで $8 \times 10^{-8} \mathrm{~A} / \mathrm{cm}^{2}$ の低イオン密 度に保ちながらイオン衝撃を行ったときの AES で測定 した表面組成変化である。 1 時間後には明瞭な差が出始 め $8 \sim 12$ 時間後には表面組成は母相の $40 \mathrm{at} \% \mathrm{Ni}$ もしく はそれよりやや銅濃度が高い平衡值を示す，選択スパッ タリング効果によるニッケル富化現象は認められない. このイオン衝撃における剝離速度は，銅に対して 1 原子 層/1150s といら極めて小さな值で，12時間後の照射イオ ン量はほぼ $10 \mathrm{~nm}$ の表面層の剝離に対応する.

\section{（d）高温スパッタリングに及ぼす金属組織の影響}




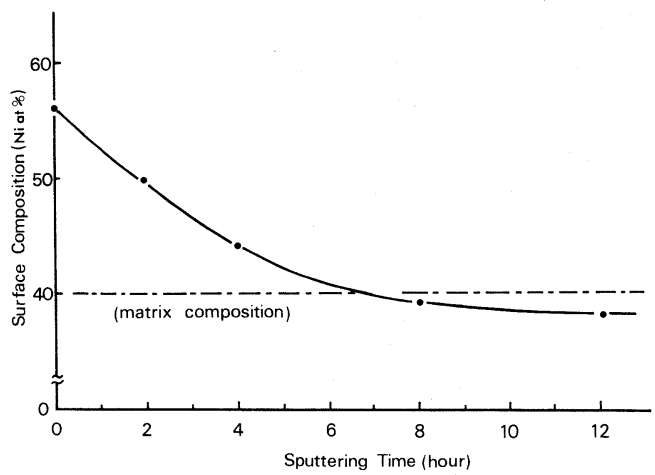

Fig. 8 Composition changes of a pre-sputtered surface of a coarse grained 40 at $\% \mathrm{Ni}$ alloy specimen after sputtering at room temperature at a current density of $0.08 \mu \mathrm{A} / \mathrm{cm}^{2}$.

Fig. 2 で示したよらに高温スパッタリングによる表面

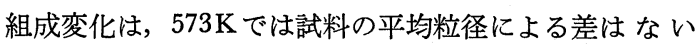
が，873K では細粒試料の方が銅の偏析量が多い，高温 におけるイオン損傷に及ぼす影響を調べる目的で，表面 形態の変化を SEM で観察した. Fig. 9 (a), (b), (c) は室 温と $873 \mathrm{~K} て ゙ ~ 40 a t \% \mathrm{Ni}$ 合金を $40 \mu \mathrm{A} / \mathrm{cm}^{2}$ のイオン密度 で 4 時間スパッタした後の SEM 写真である. 室温スパ ッタリング後の表面では各結晶粒毎の段差が明瞭であ り, 粒界は直線的である.また本研究で得た各結晶粒表面 はほぼ鏡面であるが，試料によっては粒内にピットが多 数形成されることがある.これはスパッタ時間,イオン密 度, 電解研磨による表面仕上げなどに起因すると考えら

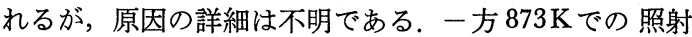
後の表面はかなり異った様子を示している，各結晶粒の 段差は室温の場合ほど大きくない，また各結晶粒の表面 は波を打った様な微細な構造を持つ．しかもそれらの形 状は結晶粒毎に異なっている，粒界近傍における損傷も 著るしく異なり， $3 \sim 10 \mu \mathrm{m}$ の周期で蛇行し， $2 \sim 3$ $\mu \mathrm{m}$ の幅の中に0. $5 \sim 1 \mu \mathrm{m}$ の穴が多数形成されている. この領域の SEM 像はコントラストが強く，2次電子放 出率がかなり高い.

Fig. 9(b) 中の数字は XMA で測定した組成 (Ni at \%) である. 粒内の組成は 42 43 at\% Ni で, 多少のニック ル富化が認められるのみである. AESの測定で得た結果 との異なりは両者の分析哚さの差によるもので，Fig. 5 で示したように粒内での欠乏層が非常に浅いことがわか る. 一方粒界損傷領域での組成は，42 75 at \% Ni でか なり銅の欠乏度合が強い．このことは粒内に比較して粒 界から表面に供給される銅の量がはるかに多く，細粒試 料では粗大粒試料よりも表面におりる銅濃度が高いとい 5 Fig. 2 と同様な結果が得られたことになる．各粒界で
のニッケル富化量と表面損傷状態との対応はあまり明膫 でないが，動きの激しい場所ではかなりニッケル富化量 が多い，また整合双晶界面では表面の形状にもニッケル 濃度にも変化は認められない。

Fig. 9 (b) に示したニッケル 富化度合のヒストグラム をFig. 10 に示した。測定点の任意性を高めるために， Fig.9 (b) より広い領域に含まれる各々の結晶 粒を 囲 む 粒界50ケ所を選んだ。ニッケル富化の分布には（Ｉ）45～ 50 at $\% . \mathrm{Ni}$ ，(II ) $60 \sim 65$ at\% Ni に2 本のピークが現わ れる.（I）のグループに属する粒界は，粒径が100 200 $\mu \mathrm{m}$ のやや大きい結晶粒どうしが接している場合が多 い. 一方（II）のグループに含まれる粒界は，粒径が30～ $60 \mu \mathrm{m}$ の比較的小さい結晶粒どうしあるいはこれらの小 さい結晶粒と大きい結晶粒とが接している場合が多い. しかし測定結果には上述のような単純な分類が出来ない 粒界も多数含まれている.

さらに詳しい解析を行らために個々の結晶粒の方位を ECP を用いて測定し，粒界の種類や構造を調べた. Fig. 11 は，(111)軸方位の結晶粒から得た ECPで，(a)はスパ ッタ前の試料から得たもので，結晶性が高いために各バ ンドは鮮明であるが，(b)はイオン衝撃を行った試料面か ら得た ECP でやや不鮮明になっている。これはイオン 衝撃により格子の乱れが生じた事や表面に微細構造が形 成されたことなどによる. 従って透過電子顕微鏡の加速 電圧を変えることで反射電子の発生領域を変化させると パターンのボケ具合が変り，イオン損傷層の深さに関す る定性的な情報が得られる。本研究の段階では十分な知 見が得られなかった。

ECP による粒界構造の解析から次のような結果を得 た. ニッケル富化度合が大きくて主に【のピークのグル ープに属する粒界は大傾角粒界 (large angle boundary) の部類に入る. 一方ニッケル富化が弱くて主に I のピー クに属する粒界は小傾角粒界 (small angle boundary) に 属している傾向がある。一般に粒界をはさんだ両側で結 晶粒の方位が 1 つの結晶軸のまわりにごくわずか傾いて いるむのが小傾角粒界と呼ばれていて，ここでの粒界エ

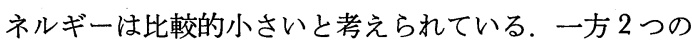
結晶粒の方位が大きく違っていて，境界での結晶の接続 がスムーズでない場合は大傾角粒界と呼ばれ，小傾角粒 界に比較すると粒界エネルギーは高く，言い換えればそ れだけ不安定な粒界と言える ${ }^{36)}$. 粒界のエネルギーは小 傾角，大傾角粒界のいずれにおいても傾角 $(\theta)$ の関数に なる．実際の試料で $\theta$ の分布があるために，Fig. 10 の様 なヒストグラムが得られたと考えられる．また粒界損傷 効果は723Kより高い温度での照射で起り始めるが，573 K以下では銅の欠乏層は XMA で検出されなかった。 

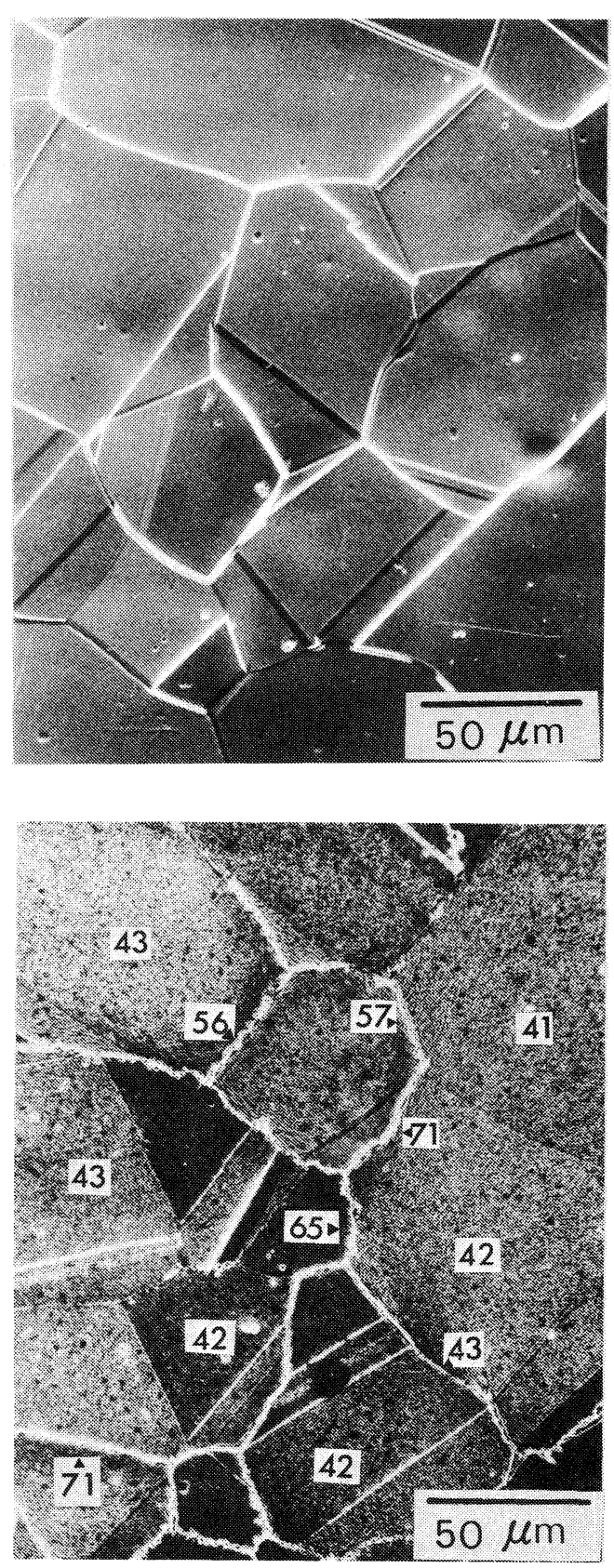

この結果は AES によって得た Fig. 1の結果と良く対応 している.

以上の結果を模式的に Fig. 12 に示した. イオン損傷 による銅の抎散には 2 種類あって，1つは結晶粒内での 格子欠陥によるもので，他方は粒界移動などの変化を伴 ら粒界損傷である。．後者は前者に比較すると 1 桁以上 深い銅の欠乏層を形成する. 従って $D^{*}{ }_{\mathrm{gr}}$ としては少くと も $D^{*}{ }_{\text {vol }}$ の $3 \sim 10$ 倍程度の大きさを持つ. 粒界から渗み (a)

(c)

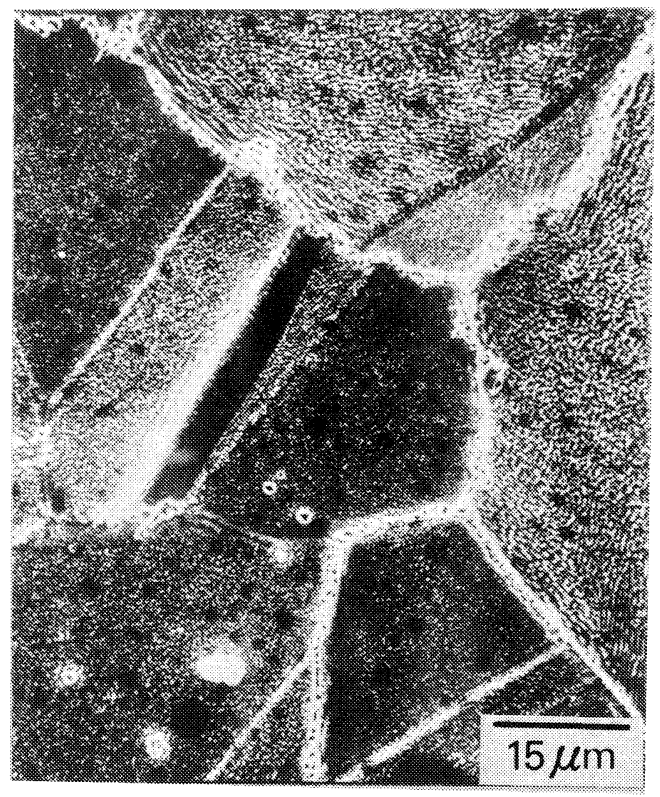

Fig. 9 SEM images of the 40 at $\% \mathrm{Ni}$ alloy surface sputtered by $3 \mathrm{keV}$ argon ion $\left(40 \mu \mathrm{A} / \mathrm{cm}^{2}, 4 \mathrm{~h}\right)$. (a) at room temperature. (b) at $873 \mathrm{~K}$. (c) High magnification image in (b). Point analysis of nickel concentration (at $\%$ ) determined by XMA method.

出した銅は表面拡散 $D_{\text {sur }}$ によって表面に一様に広がり， そのために平均結晶粒径が小さくなる程その効果は大き くなる. 粒界損傷は $723 \mathrm{~K}$ 程度より高い場合に重要にな る. 従って $D^{*}{ }_{\mathrm{vol}}$ と $D^{*}{ }_{\mathrm{gr}}$ の大小関係は温度範井で, 次の 様になる。

$$
\begin{array}{ll}
D^{*}{ }_{\mathrm{gr}}<D^{*}{ }_{\text {vol }} & (<573 \mathrm{~K}) \\
D^{*}{ }_{\mathrm{gr}}>D^{*}{ }_{\text {vol }} & (>723 \mathrm{~K})
\end{array}
$$




\section{4. 考 察}

高温における銅ニッケル合金スパッタリング現象を考 える上で，(a)銅とニッケルのスパッタ率差による選択ス パッタリング，(b)銅の表面近傍への偏析，(c)母相内での 銅の照射誘起拡散, (d)結晶粒界損傷などの役割の重要性

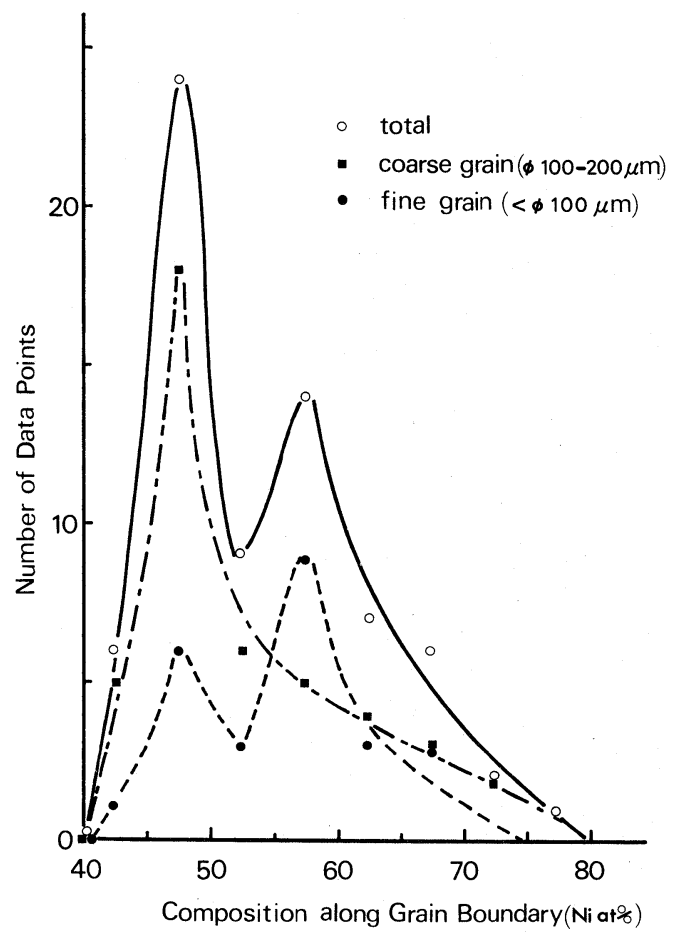

Fig. 10 Distribution of nickel concentration along the eroded grain boundary in the image of Fig. 9 (b)
を明らかにした. ここでは, 従来の研究結果との関連を 明らかにし，銅ニッケル合金の室温でのスパッタリング に及ぼす照射誘起拡散の効果を考察する.

\section{(a) 銅の表面近傍への偏析}

この合金の表面近傍層の組成が内部と異っていて，高 温になるにつれて銅の平衡偏析 (Gibbsian segregation) が起ることは $\mathrm{AES}^{37)}, \mathrm{ISS}^{38)}$ ，アトムプローブ電界イオ ン顕微鏡 ${ }^{39)}$ (AT-FIM) などの表面分析法で確認され, また熱力学的にも検討されている．銅の偏析量に関する 本研究の結果はすでに報告されている值とおおよそ一致 しているが，偏析層の厚みに関してはやや異っている. AT-FIM で Ng らが得た結果は, $923 \pm 20 \mathrm{~K} て ゙ ~ N i-3.1$ $\pm 0.5 \mathrm{at} \% \mathrm{Cu}$ の場合 $4 \sim 5$ 原子層であるのに対し，本 研究の 40 at $\% \mathrm{Ni}$ の $873 \mathrm{~K}$ における結果は 20 原子層前後 であった. 厚みの推定に本研究ではイオン衝撃法を用い ているため, ミキシングやノックオン効果による深さ方 向の誤差があって $\mathrm{Ng}$ らによる電解蒸発法の結果とは単 純には比較出来ない. しかし高分解能透過電子顕微鏡 (JEOL-200C型) を用いて格子像を観察すると ${ }^{40)}, 873 \mathrm{~K}$ でイオン衝撃した試料では $5 \mathrm{~nm}$ 以下の微細な 結晶粒が 観察されることがある. このことはイオン照射によって 格子が乱れ，アモルファス様になった試料表面近傍で, 焼鈍による再結晶化が起り始めていることを示す．この 様な組織の変化を伴う場合には, Gibbs の平衡偏析のみ ならずやや樑い領域で照射誘起偏析とも呼ぶべき現象も 同時に起っている可能性は十分ある. Ishitani ${ }^{41)} ら か ゙$ 行 ったモンテカルロ計算結果によれば，アモルファス様の 銅ターゲルト中での $5 \mathrm{keV}$ のアルゴンイオンの飛程は, $3 \sim 7 \mathrm{~mm}$ 程度であるから, 焼鈍による微細結晶化がこ の領域で進むと考えられるので，本研究で得た銅偏析層

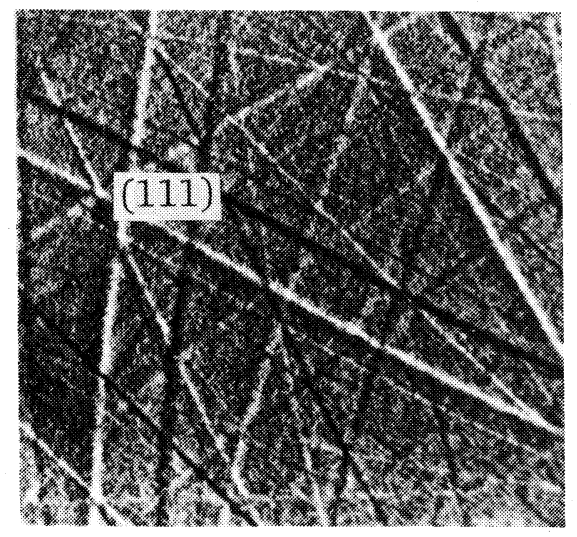

(a)

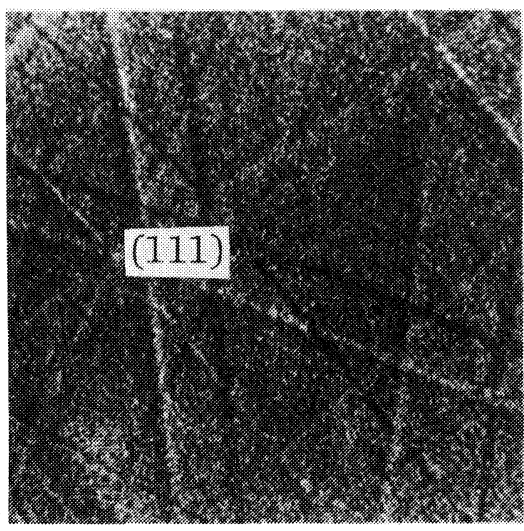

(b)

Fig. 11 Electron channeling patterns of $40 \mathrm{at} \% \mathrm{Ni}$ alloy specimen. (a) before sputtering. (b) after sputtering at room temperature. 


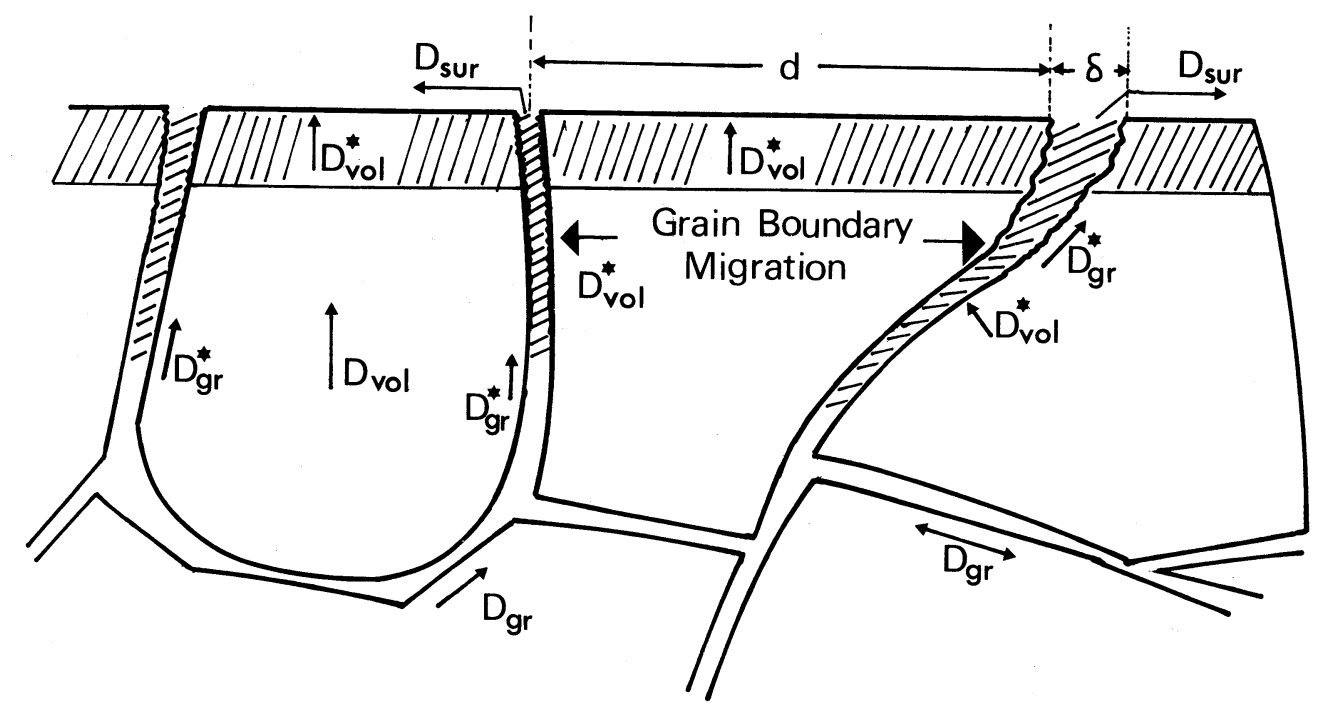

Fig. 12 Schematic model of specimen structure for the diffusion flux of copper during sputtering at elevated temperatures. In the hatched regions the enhancement of diffusion occurred.

の厚みが Gibbs の平衡偏析より厚いという結果を説明出 来る.

\section{（b）銅の照射誘起拡散}

イオン衝撃によりいわゆる Frenkel 対（空孔と格子間 原子）が形成された状態では原子の移動が速くなること は良く知られているが，高温照射下では欠陥の生成と再 結合による消滅が繰り返される他，欠陥は表面や粒界に 移動して消減するため, 欠陥の拡散への影響は複雑にな る. 拡散の機構を決めるためには活性化エネルギー, 頻 度因子を求めることが最も有効な方法である.Fick の第 2 法則にスパッタリングの剥離効果を入れた式(1)の解法 はかなりむずかしいが, 定常状態の解は解析的に解くこ とが可能で式(2)を得る. $D^{*}{ }_{\text {vo1 }}$ が低イオン密度領域でやや 小さくなる傾向があるものの, 明瞭なイオン密度依存性 はない. 本来 $D^{*}{ }_{\mathrm{vol} 1}$ は欠陥濃度に比例すると考えられる が，本研究の場合拡散の促進に寄与する欠陥濃度はかな り飽和している可能性がある.

本研究で得た拡散の活性化エネルギーは, 約5.4 40.5 $\mathrm{kcal} / \mathrm{mol}$ であるが, Swartzfager ${ }^{12)}$ ら が $\mathrm{Cu}-50$ at \% Ni 合金の多結晶試料を $473 \sim 773 \mathrm{~K}$ の温度範囲で $2.0 \mathrm{keV}$ の アルゴンイオン衝撃を行い, ISS を用いて銅の欠乏層の 分布を測定して得た活性化エネル ギーは $1.7 \mathrm{kcal} / \mathrm{mol}$ $(0.1 \mathrm{eV})$ であった. 一方 Skikata らも同じ組成の合金 で473 673Kの温度範囲で $500 \mathrm{eV}$ のアルゴンイオンに よる銅の欠乏層の形成を報告している，拡散定数, 活性 化エネルギーを筆者が式(2)，(3)より求め Fig. 8 に示し た. 活性化エネルギーは約 $11 \mathrm{kcal} / \mathrm{mol}$ でやや大きな值
を示す. 特に Shikata らの值が大きい理由は不明である が，試料平均粒径や加速エネルギーの差が欠乏の表面か らの形成や分布に影響している可能性がある.

いずれにしろ照射誘起拡散は体拡散に比較すると活性 化エネルギー，頻度因子が小さいという特色を持ち，格 子間原子拡散機構によることを示唆している. 照射誘起 拡散の機構は次の様に考えることが出来る.イオン照射 により形成された銅の格子閒原子は銅の偏析を起しなが ら表面に移動する。一方ニッケルの格子間原子はイオン の飛程よりはるかに哚い領域まで侵入し, さらに格子位 置の銅原子と置換し，再び銅の格子間原子は表面近傍に 流れ出すために銅の欠乏層もしくはニッケル富化層が形 成されることになる.なお格子間原子と格子位置の原子 の置換に要する活性化エネルギーは極めて小さいと考え られている(2). このモデルの妥当性を検証するために透 過電子顕微鏡による空孔と格子間原子の挙動に関する観 察を現在行っている.

\section{(c) 結晶粒界損傷}

イオン照射によって形成された点欠陥は移動して粒界 や表面で消滅すると考えられるので， $723 \mathrm{~K}$ 以上のスパ ッタリングで認められる銅の粒界欠乏層は粒界と欠陥の 相互作用で起った現象である. 冷間圧延を受けた試料を 焼鈍すると再結晶化が起るが, 歪の回復とともに結晶成 長は止まり, 結晶粒界も安定化する ${ }^{43)}$. このとき大きな 結晶粒に囲まれた小さい結晶の粒成長は抑制されるた め，高い粒界エネルギーを保持したままになる．イオン 照射を受けると粒界近傍に欠陥が集まり，もし試料温度 
が高いと粒界移動を起して粒界エネルギーが放出されて 粒界の安定化が起る. それに伴って拡散が促進されて銅 の表面への供給が進むと解釈出来る. 粒界エネルギーの 大きい大傾角粒界で粒界移動が激しく銅の欠乏度合が大 きいのはそのためである.

$723 \mathrm{~K}$ 以上のスパッタリングでは粒界損傷による拡散 の寄与があるので, 表面へ銅を供給する 拡散束として Fick の第 1 法則を次のように書改める必要がある.

$$
J=-D *_{\mathrm{vol}}\left(\frac{\mathrm{d} c}{\mathrm{~d} x}\right)_{\mathrm{vol}}-D{ }_{\mathrm{gr}} A_{\mathrm{eff}}\left(\frac{\mathrm{d} c}{\mathrm{~d} x}\right)_{\mathrm{gr}}
$$

ここで $D^{*}{ }_{\mathrm{vol}}, D^{*}{ }_{\mathrm{gr}}$ 法損傷により促進された体散拡なら びに粒界拡散定数, $(\mathrm{d} c / \mathrm{d} x)_{\mathrm{vol}},(\mathrm{d} c / \mathrm{d} x)_{\mathrm{gr}}$ は対応する濃度 勾配, $A_{\text {eff }}$ は有効な拡散面の割合である ${ }^{44)}$. Fig. 11 の模 式困を使って(4)式の第 2 項の寄与を検討してみる. 結晶 粒径 $d$ に対して粒界幅 $\delta$ で粒界拡散が起ったとすると, $A_{\text {eff }}$ は近似的に $4 \delta / d$ となる. 損傷前の試料の $\delta$ は 0.5 $\sim 1 \mathrm{~nm}$ 程度であるから，50〜150 $\mu \mathrm{m} \phi$ の平均粒径を持 つ細粒試料では $A_{\text {eff }}$ はおおよそ $10^{-5}$ 程度にしかならな い. $723 \sim 873 \mathrm{~K}$ の温度範囲で正常な拡散定数 $D_{\mathrm{gr}}$ が $D_{\mathrm{vol}}$ より $10^{2} \sim 10^{3}$ 倍大きいとしても, 粒界拡散による寄与は $10^{-3} \sim 10^{-2}$ で無視出来る. ところが本研究で明らかにし たように，粒界移動を伴った粒界損傷幅は 2〜3 $\mu \mathrm{m}$ も あるので, $A_{\text {eff }}$ は $10^{-1} \sim 10^{-2}$ になり，(4)式の第 2 項は細 粒試料で無視出来なくなる.

損傷層内で $D^{*}{ }_{\mathrm{gr}}$ が $D^{*}{ }_{\mathrm{vol}}$ よりどの程度大きいかは今 のところ明らかでないが，粒界損傷領域での銅の欠乏層 の深さが数 $\mu \mathrm{m}$ から $10 \mu \mathrm{m}$ あるので, 粒内欠乏層の数 10 から 100 倍の深さがあることになり，単純に $\sqrt{D t}$ を 考慮すれば $D^{*}{ }_{\mathrm{gr}}$ は $D^{*}{ }_{\mathrm{vol}}$ の 5 10倍となる. したがっ て数 $10 \mu \mathrm{m}$ 程度の粒径を持つ試料での粒界からの拡散 束は粒内からのものと同程度となる. それ以下の粒径を 持つ試料（とくに蒸着膜など）を用いた実験では粒界損 傷による促進された拡散挙動を測定する可能性があるの で注意する必要がある。本研究で用いた粗大粒試料 $(\phi 1$ $\sim 3 \mathrm{~mm}$ ) では粒界からの拡散束の効果は無視出来るの で，単結晶試料と同等と考えて良い.

（d）銅ニッケル合金の選択スパッタリング

室温でこの合金を Ar イオンで衝撃した後の表面でニ ッケル富化が AES で観察されることは，銅の方がニッ ケルよりスパッタ率が大きいことによる選択スパッタリ ング現象と考えられてきた ${ }^{45 \sim 49)}$. ところが Okutani ${ }^{11)}$ は ISS を用いて室温でイオン衝撃した 50 at \% Ni 合金 の最外層の組成は母相と同じかやや銅濃度が高いという 結果を得た. モンテカロル計算結果によれば41)，スパッ タされた物質の大部分は表面第 1 層から飛びだすので, 定常状態でスパッタされた合金が母相と同一組成である
といら実験事実を説明するためには，銅とニッケルとが 同じスパッタ率を保ちながらスパッタリングが進行する ことになり, 選択スパッタリングは存在しないという正 反対の結論が得られる

本研究で明らかにしたように，スパッタリング中には 照射誘起拡散，偏析なども同時に起るために，表面近傍 の組成やスパッタされた物質の組成は, 室温においてす ら照射条件に左右されるみかけの值であって, 必ずしも スパッタリングそのものによる組成変化を反映している とは限らない．また分析樑さの異なる手段による組成結 果に基づいて選択スパッタリングの議論を行うことは適 当でない. そこで篗者はスパッタリングの素過程にのみ 注目して選択スパッタリングを次の様に定義する.「合 金を構成する各々の元素の持つスパッタ率差が保存され てスパッタリングが進行する場合が選択スパッタリング である」.この定義に基いて, AES と ISS による結果を 説明し，銅ニッケル合金の選択スパッタリングの存在に ついて考察する.

(i) AES 観察によるニッケル富化現象

試料表面に入射したイオンは格子位置のニッケルや銅 と衝突を繰り返しながら原子のミキシングを起す．スパ ッタ率の高い銅は優先的に表面近傍へ移動する確率が高 く，母相組成より銅濃度が高い合金が剝離される. スパ ッタリングの進行につれて形成されるミキシング層の深 さは表面から $5 \sim 7 \mathrm{~nm}$ で, それより深い領域の組成は 影響を受けない.そのためミキシング層内の 銅は欠乏 し，剝離される合金中の銅濃度は次第に低くなる．定常 状態では母相と同一組成の合金が剝離され，一方 AES の分析深さがミキシングン゙ーンより浅いためにスパッタ された表面での平均組成はニッケルの富化を示す.

上述のモデルを裏付ける実験が Goto らによってなさ れた ${ }^{51)}$. 銅とニッケルの同時蒸着法で $\mathrm{Ta}$ 䈃上に作成し た合金の薄膜を液体窒素温度近傍でスパッタし，試料表 面組成変化を AES で測定して次の結果を得た. (a)スパ ッタリングの進行でニッケル富化が起り, やがて定常值 を示す. (b)ミキシング層が $\mathrm{Ta}$ 表面に到達するとさらに ニッケル富化が強くなる. (a)の挙動は本研究で示した結 果と同じである. (b)は選択スパッタリング効果を明瞭に 示している. ミキシング層が Ta 表面に到達すると母相 からの銅ニッケルの供給がなくなり，スパッタ率の高い 銅の優先的剝離が進行してニッケル富化が起ると説明出 来る.

(ii) ISS による表面組成変化

本研究で解析した拡散定数の結果から, 室温において も秒の単位で銅原子が格子間距離程度移動出来ることが 明らかになった. ISS による組成分析結果を説明するた 
めに，表面に移動する拡散束 $(J)$ を次式によって概算 した.

$$
J=-D^{*}{ }_{\text {vol }} \frac{\mathrm{d} c}{\mathrm{~d} x}
$$

AES で測定されるニッケルで富化したミキシング 層か ら Gibbs の表面偏析によって第 1 層に銅が集まるとする と, 表面 $1 \sim 2$ 原子層の間で 20 at \%程度の 濃度勾配 が 出来るので, $J$ は $10^{14} \sim 10^{13}$ atoms $/ \mathrm{cm}^{2} \mathrm{~s}$ 程度の量にな る. なお銅原子の体積濃度と表面濃度としてそれぞれ $8.41 \times 10^{22}$ atoms $/ \mathrm{cm}^{3}, 3.06 \times 10^{15}$ atoms $/ \mathrm{cm}^{2}$, 拡散定数 に $1 \times 10^{-16} \mathrm{~cm}^{2} / \mathrm{s}$ の值を用いた. この $J$ の值は 1 原子 層を銅で被うのに数十〜数百秒要することを意味する. Okutani らのISSに用いた照射条件 $(3 \mathrm{keV}, 13 \mu \mathrm{A} /$ $\mathrm{cm}^{2}$ ) では 1 原子層の剝離に要する時間が 数十秒程度 で あるから，J は剝離速度に比較してやや小さめである. 表面近傍では点欠陥のトラップ作用が少ないために，こ の領域での $D^{*}$ は銅の欠乏層の深い領域から算出した值 より大きいことは十分あり得るので，スパッタ中に第 1 層を母相と同一に保つことは可能である. Swartzfagerら も指摘している AES と ISS による表面近傍の 組成差 は, 表面 1 層におりる偏析挙動と照射誘超拡散によって 説明出来る.

しかし拡散束が無視出来ない值を持つとすれば，室温 においても表面組成が剝離速度と拡散速度の釣合で決る 見かけの值にすぎない. Fig. 7 に示した AES による結 果は上述の議論を補足することが出来る。イオン密度を $8 \times 10^{-8} \mathrm{~A} / \mathrm{cm}^{2}$ 保った場合の 1 原子層の剝離に要する時 間は1000秒以上で, 明らかに剝離速度の方が遅くなる. その結果定常状態では AES で測定される表面 4 5 原 子層までが母相と同一になり，選択スパッタリングによ るニッケル富化現象は全く認められなくなる．イオン照 射時間が12時間程度あるので，この間における残留ガス の吸着による組成変化などもさらに検討する必要はあ る.しかしイオン照射なしで試料を真空中に放置したの みではこの組成変化が認められないので，照射誘起拡散 によって銅の移動が起ったものと本研究では解釈した. 以上の結果を考慮すると, 挔散速が無視出来る高いイオ ン密度においても ISSによる最外第 1 層の組成が母相と 同一に保たれているかという新たな疑問が生じる。試料 を液体窒素温度近くにすると拡散を抑制出来るので入射 イオン密度依存性の議論がやり易くなるのであろら.

最後にISS.AESによる表面近傍の銅の分布からこの合 金の選択スパッタリングについて筆者の見解を述べる. 低エネルギーの AES による表面 $2 \sim 3$ 原子層の組成分 析ではニッケル富化が認められるので， 2 層目以下には かなりニッケルで富化した層が存在することになる， ス
パッタリングによって第 1 層目の原子が剝離される確率 はかなり高いと考えられる. しかし 2,3 層目の寄与が あれば銅がニッケルより大きいスパッタ率を保ちながら スパッタリングが進行しても，定常状態では母相と同一 の組成で合金が剝離されることは可能である．また表面 は理想的な平面でなく，表面の剝離によって微細な凹凸 が形成され，かつ個々の原子にはイオンが斜入射する効 果も加わるので， $2 ， 3$ 層目の原子も飛び出し易くな る. 本研究の範囲では ISS と AES による表面組成の 差また ISSによる結果と選択スパッタリングの関連を まだ十分に説明することは出来ない. しかし銅とニッケ ルのスパッタ率が同一に保たれながらスパッタリングが 進行し, 選択スパッタリングは無いというモデルを積極 的に支持出来る知見も得られなかった.

\section{5. 結語}

（1）銅ニッケル合金を高温で Ar イオン衝撃すると， 銅欠乏層が形成され，その深さは照射条件によっては873 $\mathrm{K}$ で表面から $100 \mathrm{~nm}$ 以上に及ぶ.

（2）銅の欠乏層は格子間原子拡散機構によるもので， 活性化エネルギーは5.4 $00.5 \mathrm{kcal} / \mathrm{mol} \quad(0.2 \sim 0.3 \mathrm{eV})$ である。

（3） $723 \mathrm{~K}$ 以上では粒界損傷が著るしく,粒界移動や粒 界に沿った銅の欠乏層が $1 \mu \mathrm{m}$ 以上の媣い領域 まで及 ぶ.

(4) 合金のスパッタ中スパッタ率は銅の方がニッケル より大きいために選択スパッタリングが起り，イオンの 飛程内でミキシング層が形成され，この層内は母相より ニッケルが富化している.

(5) ISS によって示された最外一層の組成が母相と同 一であることは，室温における銅照射誘起拡散によって 定性的な説明が可能である.

\section{謝 辞}

本研究を進めるにあたりご指導賜った電子技術総合研 究所極限技術部長 中山勝矢博士, 同所同部宇宙環境技 術研究室長 小野雅敏博士, 東京大学生産技術研究所 石田洋一教授, 同所 古山直行博士, 大阪大学 志水隆 一助教授, 大阪電気通信大学 越川孝範助教授に媣く感 謝する．また試料をご提供下さった東北大学金属材料研 究所 広川吉之助教授, XMA の測定に便宜を計って下 さった東京大学生産技術研究所 安井至助教授に深くお 礼申し上げる. 筆者は昭和 55,56 年度東京大学生産技術 研究所流動研究員の機会を与えもれた. ここに謝意を表 わす. 


\section{〔文献〕}

1) M. L. Tarng and G. K. Wehner: J. Appl. Phys. 42 (1971) 2449.

2) P. M. Hall and J. M. Morabito: Surf. Sci. 54 (1976) 79.

3) C. Stein: Critical Materials Problems in Energy Production (Academic Press., New York 1976) Chap. 3.

4) S. Veprek and M. Venugopallan: Plasma Chemistry I (Springer-Verlag, Berlin-Heiderberg 1980) p. 45.

5) 毛利 衛, 山科俊郎 : 真空 10 (1981) 533.

6) N. Lagreid and G. K. Wehner: J. Appl. Phys. 32 (1961) 365.

7) N. Matsunami et al.: Energy Dependence of Sputtering Yields of Monoatomic Solids (Institute of Plasma Physics, Nagoya University, 1980).

8）門間改三，須藤 一, 及川 洪 : 日本金属学 会誌 28 (1964) 192.

9) D. B. Butrymowicz, Manning and M. E. Read: J. Phys. Chem. Ref. Data 5 (1976) 142.

10) 柿林博士, 毛利 衛, 渡辺国昭, 山科俊郎 : 真空 22 (1979) 220.

11) T. Okutani, M. Shikata and R. Shimizu: Surf. Sci. 99 (1980) L410.

12) D. G. Swartzfager, S. B. Ziemecki and M. J. Kelly: J. Vac. Sci. Technol 19 (1981) 185.

13) K. Nakayama, M. Ono and H. Shimizu: J. Vac. Sci. Technol 9 (1972) 749.

14) H. Shimizu, M. Ono and K. Nakayama: Surf. Sci. 36 (1973) 817.

15) H. Shimizu, M. Ono and K. Nakayama: J. Appl. Phys. 42 (1975) 460.

16) H. Shimizu, N. Koyama and Y. Ishida: Jpn. Appl. Phys. 19 (1980) L671.

17) H. Shimizu, M. Ono, N. Koyama and Y. Ishida: Jpn. J. Appl. Phys. 19 (1980) L557.

18）清水 肇, 古山直行, 石田洋一, 小野雅敏, 工藤隆一：日本金属学会誌 45 (1981) 210.

19) 清水 肇, 古山直行, 石田洋一 : 同上 45 (1981) 768.

20) L. E. Rehn, S. Danyluk and H. Wiedersich: Phys. Rev. Lett. 43 (1979) 1437.

21) M. Shikata and R. Shimizu: Surf. Sci. 97 (1980) L363.

22) Y. Takasu, H. Shimizu, S. Maru, M. Tomori and Y. Matsuda: Corr. Sci. 16 (1976) 159.

23）村上 寛, 清水 肇 : 第 22 回真空に関する連 合講演会 7AP-1.

24) H. Shimizu, M. Ono and K. Nakayama: Proc. of the 7th Intern. Vac. Congr. and 3rd Intern. Conf. Solid Surfaces (Vienna 1977) p. 2359.
25）清水 肇, 判治克己, 石黒勝彦, 本間禎一： 日本金属学会誌 42 (1978) 1071.

26) M. Ono, H. Shimizu and K. Nakayama: Surf. Sci. 52 (1975) 681.

27) G. R. Booker: Modern Diffraction and Imaging Technique in Material Science (North-Holland Pub. Co. Amsterdam 1969) p. 644.

28）市ノ川竹男 : 応用物理 41 (1972) 166, 981.

29) O. C. Wells: Scanning Electron Microscopy (McGraw-Hill U.S.A. 1974) Chap. 7.

30) H. Shimizu, N. Koyama and Y. Ishida: Proc. of the 5th Intern. Conf. on Texture of Materials (Aachen 1978) p. 431.

31) 幸田成康:改訂金属物理学序論（コロナ社, 1964) 第 6 章.

32) A. H. Eltoukhy and J. E. Greene: J. Appl. Phys. 51 (1980) 4444.

33) P. D. Tounsend, J. C. Kelly and N. W. Hartley: Ion Implantation and Their Application (Academic Press London 1976) p. 105.

34) M. Doyama and S. Yoshida: Progress in The Study of Point Defects (University of Tokyo Press 1977) Table II p. 322.

35）石野 亲, 照射損傷（東京大学出版会 1979).

36) G. A. Chawick and D. A. Smith: Grain Boundary Structure and Properties (Academic Press, London 1976) Chap. 5.

37) C. R. Helms: J. Catalysis 36 (1975) 114.

38) H. H. Brongersma, M. J. Sparnaacy and T. M. Buck: Surf. Sci. 71 (1978) 657.

39) Yee. S. Ng, T. T. Song and S. B. Mclane, Jr.: Phys. Rev. Lett. 42 (1979) 588.

40）石田洋一, 清水 肇, 古山直行: 未発表.

41) T. Ishitani and R. Shimizu: Phys. Lett. 46A (1974) 487.

42）橋口隆吉, 近角聡信編 : 結晶格子欠陥（朝倉 書店 1969) p. 233.

43）渡辺慈郎，斉藤安俊 : 基礎金属材料（共立出 版1979）第 8 章.

44）渡辺亮治, 諸正太郎共訳 : ガイ著「材料科学 （上）」(丸善 1974) p. 248.

45) P. S. Ho, J. E. Lewis, H. S. Wildman and J. K. Howard: Surf. Sci. 57 (1976) 393.

46) Ho: Surf. Sci. 72 (1978) 253.

47) N. Saeki and R. Shimizu: Jpn. J. Appl. Phys. 17 (1978) 59.

48) K. Goto, T. Koshikawa, K. Ishikawa and R. Shimizu: J. Vac. Sci. Technol. 15 (1978) 1695.

49) T. Koshikawa, K. Goto, N. Saeki, R. Shimizu and E. Sugata: Surf. Sci. 79 (1979) 461.

50) 志水隆一, 他 : 応用物理 50 (1981) 483.

51) K. Goto, T. Koshikawa, K. Ishikawa and R. Shimizu: Surf. Sci. 75 (1978) L373. 